\title{
PENGARUH MIND MAPPING TERHADAP PENGUASAAN KONSEP KIMIA PADA MATERI HIDROKARBON SISWA KELAS XI MAN 1 KOTA BIMA
}

\author{
Elfi Fitrah, Nurfidianty Annafi dan Putri Ayu Mutmainnah \\ Program Studi Pendidikan Kimia STKIP Bima \\ E-mail: fitrahelfhy@gmail.com
}

\begin{abstract}
ABSTRAK
Penelitian ini bertujuan untuk mengetahui ada atau tidaknya pengaruh mind mapping terhadap penguasaan konsep kimia pada materi hidrokarbon siswa kelas XI MAN 1 Kota Bima yang terbagi dari 5 kelas dan terdiri dari 115 siswa dengan kelas XI IPA 5 (eksperimen) dan kelas XI IPA 4 ( kelas kontrol). Pada kelas eksperimen diterapkan mind mapping sebagai sampel setelah sebelumnya pemilihan sampel ini menggunakan teknik non probality sampling dengan jenis purposiv sampling. Jenis penelitian ini adalah quasi eksperiment. Dari hasil pengolahan data dapat dilihat pengaruh mind mapping terhadap penguasaan konsep siswa. pengolahan data hasil penelitian menggunakan uji Mann Whitney $U$. Data nilai posttest penguasaan konsep siswa dapat dilihat dari nilai Asym sig. (2-tailed), yaitu 0,000 sehingga hipotesis Ho yang diajukan ditolak karena jika nilai asymp sig $<0.05 \quad \mathrm{Ha}_{a}$ diterima. Dari hasil pengolahan data dapat disimpulkan bahwa terdapat pengaruh mind mapping terhadap penguasaan konsep kimia pada materi hidrokarbon siswa kelas XI MAN 1 Kota Bima.
\end{abstract}

Kata kunci : mind mappig, penguasaan konsep, dan Hidrokarbon.

\section{PENDAHULUAN}

Pendidikan merupakan jalan pertama setiap manusia yang ingin mengubah diri dari segala segi dalam diri, baik perilaku maupun sifat. Teori pendidikan merupakan landasan dan pijakan awal dalam pengembangan praktik pendidikan, misalnya pengembangan kurikulum, manajemen sekolah dan proses belajar-mengajar. Kurikulum dan pembelajaran memiliki keterkaitan dengan teori pendidikan atau dalam penyusunan suatu kurikulum dan rencana pembelajaran ini mengacu pada teori pendidikan (Aas Siti Sholichah, 2018).

Kimia merupakan cabang ilmu pengetahuan yang mendukung perkembangan ilmu pengetahuan yang perlu terus dikembangkan. Salah satu cara yang dapat ditempuh agar kimia terus berkembang adalah dengan menjadikan kimia sebgai salah satu mata pelajaran yang disenangi siswa di sekolah. Meskipun kimia akan ilmu yang berperan penting dalam perkembangan IPTEK dan dekat dengan kehidupan sehari-hari siswa, tetapi kimia masih dianggap sebagai salah satu mata pelajaran yang susah untuk dipahami oleh sebagian siswa (Baeti Fitriana, 2015).

Ilmu kimia di pandang sangatlah sulit oleh untuk menyesuaikan strategi belajar yang tepat sehingga prestasi belajar yang diharapkan mampu mencapai KKM 75 tidak mampu diraih. Tinggi rendahnya prestasi belajar siswa ditentukan oleh hasil belajar siswa. Penguasaan konsep yang baik akan membuat siswa dapat berpikir pada tingkatan yang lebih tinggi lagi. Penguasaan konsep yang baikpun semestinya akan mempermudah mereka dalam mencapai kriteria ketuntasan minimal (KKM) yang telah ditetapkan oleh sekolah, dalam usaha penguasaan konsep kimia di SMA, guru perlu menerapkan metode pembelajaran yang memungkinkan siswa untuk mencapai kebutuhan tersebut (Miftakhul Huda, 2006:184). Guru seharusnya kreatif dan inofatif dalam menggunakan perangkatperangkat metodis dalam pembelajaran kimia. Dengan demikian, akan mempermudah siswa 
membangun pengetahuannya. Hasil observasi peneliti terhadap siswa, ketika guru menggunakan metode ceramah siswa merasa bosan dan malas sedangkan ketika diberi tugas kelompok diskusi siswa merasa lebih leluasa bermain. Dengan menggunakan strategi mind mapping memudahkan untuk melihat secara keseluruhan, membatu otak dalam mengatur, mengingat, membandingkan dan membuat hubungan serta memudahkan penambahan informasi baru, pengkajian ulang bisa lebih tepat, dan setiap peta bersifat unik.

Dari pertimbangan tersebut, peneliti tertarik menjadikan MAN 1 Kota Bima sebagai objek penelitian, mengingat kondisi siswa yang kurang aktif, kurang perhatian dan mengalami kejenuhan dalam belajar kimia, selain itu model pembelajaran ini belum pernah diterapkan. Sehubungan dengan hal tersebut maka peneliti tertarik untuk melakukan penelitian yang berjudul "PENGARUH MIND MAPPING TERHADAP PENGUASAAN KONSEP KIMIA PADA MATERI HIDROKARBON SISWA KELAS XI MAN 1 KOTA BIMA".

\section{METODE}

Jenis penelitian ini adalah penelitian eksperimen, berupa quasiexperiment design dengan jenis rancangan yang digunakan adalah non equivalent control group design. . Adapun rancangan yang dimaksud dapat dilihat pada tabel berikut.

Tabel 1. Non Equivalent Control Group Design

\begin{tabular}{|c|c|c|c|}
\hline Kelas & Pre-test & Treatment & Post-test \\
\hline Eksperimen & 01 & $\mathrm{X}$ & 02 \\
\hline Kontrol & 03 & - & 04 \\
\hline
\end{tabular}

Keterangan :

$0_{1}$ : Hasil pre-test pada kelas eksperimen.

$\mathrm{O}_{3} \quad$ : Hasil pre-test pada kelas kontrol.

$\mathrm{X}$ :Pemberian perlakuan pada kelas eksperimen berupa media mind mapping.

$\mathrm{O}_{2} \quad$ : Hasil post-test pada kelas eksperimen.

$\mathrm{O}_{4}$ : Hasil post-test pada kelas kontrol(Sugiyono, 2010)

\section{Waktu dan Tempat Penelitian \\ Waktu Penelitian}

Waktu penelitian dilakukan pada semester ganjil tahun pelajaran 2019/2020 dan dilakukan selama 3 minggu pada bulan Agustus.

\section{Tempat penelitian}

Penelitian akan dilakukan di MAN 1 Kota Bima.

\section{Subjek Penelitian \\ Populasi}

Populasi yang digunakan dalam penelitian ini adalah seluruh siswa kelas XI IPA MAN 1 Kota Bima tahun pelajaran 2019/2020 yang terdiri dari 4 kelas yang berjumlah 115 siswa.

\section{Sampel}

Sampel yang digunakan dalam penelitian ini adalah sebanyak 2 kelas dengan jumlah 56 siswa, pengambilan sampel menggunakan teknik non probalitty sampling dengan jenis proposive sampling. 
Tabel 2. Jumlah siswa kelas eksperimen dan kelas kontrol.

\begin{tabular}{|l|c|}
\hline \multicolumn{1}{|c|}{ Kelas } & Jumlah Siswa \\
\hline XI Mia 4 (kontrol) & 28 \\
\hline XI Mia 5 (eksperimen) & 28 \\
\hline Jumlah & 56 \\
\hline
\end{tabular}

Sumber : Dokumentasi XI MAN 1 Kota Bima.

\section{Variabel Penelitian}

Peneliti ini menggunakan dua variabel yaitu:

\section{Variabel bebas}

Variabel bebas merupakan variabel yang mempengaruhi atau yang menjadi sebab perubahannya atau timbulnya variabel dependen/terikat (sugiyono,2013), dalam penelitian ini variabel bebas $(\mathrm{X})$ adalah strategi mind mapping.

\section{Variabel terikat}

Variabel terikat merupakan variabel yang dipengaruhi atau yang menjadi akibat karena adanya variabel bebas (Sugiyono,2013). Variabel $(Y)$ dalam penelitian ini adalah penguasaan konsep siswa kelas XI MAN 1 Kota Bima.

\section{Instrumen Penelitian}

Instrumen tes digunakan untuk mendukung alat ukur pencapaian keberhasilan dalam meningkatkan penguasaan konsep siswa. Dalam hal ini, peneliti menggunakan tes non objektif dengan pemilihan butir-butir soal esay yang berjumlah 5 item soal yang mengacu kepada indikator penguasaan konsep siswa.

\section{Teknik Pengumpulan Data}

Teknik pengumpulan data pada dalam penelitian ini yaitu memberikan tes pada siswa sebelum memberikan perlakuan (pre-test) da setelah memberikan perlakuan (posttest). Hasil tes merupakan merupakan data hasil penelitian.

\section{Pengujian Instrumen Isi}

Penelitian ini hanya menggunakan uji validitas. Adapun uji validitas yang digunakan adalah validitas isi. Dalam melakukan validitas isi peneliti meminta ahli untuk melakukannya yaitu satu dosen dari program studi pendidikan kimia yakni Ibu Nurfidianty Annafi, M.Pd. dan guru mata pelajaran kimia kelas XI MAN 1 kota Bima Ibu Nurmi, S.Ag.

\section{Teknik Analisis Data}

\section{Analisis data kuantitatif}

Untuk menganalisis data hasil penguasaan konsep siswa digunakan tes esay dengan mengisi jawaban yang baik dan benar pada materi hidrokarbon yang terdiri dari 5 butir soal. Semua uji statistik dalam penelitian ini dilakukan dengan menggunakan bantuan SPSS versi 22.

\section{Uji Prasarat}

\section{Uji normalitas}

Uji Normalitas adalah uji yang dialakukan untuk mengetahui apakah data yang digunakan berdistribusi normal atau tidak. Untuk mengetahui kenormalan data, peneliti menggunakan Shapiro-Wilk Test dengan taraf signifikan 0,05.

Pedoman pengambilan keputusan adalah: 
$\mathrm{H}_{0}$ : sampel berasal dari populasi yang berdistribusi tidak normal

$\mathrm{H}_{\mathrm{a}}$ : sampel berasal dari populasi yang berdistribusi normal

$\mathrm{H}_{0}$ diterima jika nilai sig $<0,05$ dan Ha diterima jika nilai sig $>0,05$.

\section{Uji homogenitas}

Uji homogenitas adalah uji persayaratan analisis kelayakan data. Untuk mengetahui kelayakan data atau tidak, uji homogenitas yang digunakan dalam percobaan ini adalah levene statistics test.

Pedoman pengambilan keputusan adalah:

$\mathrm{H}_{0}$ : sampel penelitian mempunyai variansi yang tidak homogen

$\mathrm{H}_{\mathrm{a}}$ : sampel penelitian mempunyai variansi yang homogen

Terima $\mathrm{H}_{0}$ jika nilai sig $<0,05$ dan $\mathrm{H}_{\mathrm{a}}$ diterima jika nlai sig $>0,05$

\section{Uji Hipotesis}

Uji hipotesis akan dilakukan setelah melakukan uji prasarat . jika berasal dari populasi yang berdistribusi normal dari sampel yang bervariansi homogenn. Maka, uji in akn menggunakan uji independent sample T-test.

Rumus hipotesis yang diajukan:

$\mathrm{H}_{0}$ : tidak terdapat perbedaan rata-rata penguasaan konsep siswa antara kelas eksperimen dan kelas kontrol pada materi hidrokimia.

$\mathrm{H}_{\mathrm{a}}$ : terdapat perbedaan rata-rata pemahaman konsep siswa antara kelas eksperimen dan kelas kontrol pada materi hidrokarbon.

Pengambilan keputusan pada uji ini yaitu: Jika nilai signifikan (2-tailed) $>0,05$ maka $\mathrm{H}_{0}$ di terima, sebaliknya jika nilai signifikan (2-tailed) $<0,05$ maka $\mathrm{H}_{0}$ diterima dan $\mathrm{Ha}$ ditolak, hal ini berarti ada pengaruh mind mapping terhadap penguasaan konsep siswa. Jika sampel tidak berdistribusi normal uji hipotesis akan dilakukan dengan teknik uji statistika nonparametrik yaitu Mann-whitney apabila syarat jumlah dan normalitas data tidak terpenuhi. Uji statistik akan dilakukan dengan bantuan SPSS versi 22.

Pada uji man-whitney pengambilan keputusannya adalah sebagai berikut: jika nilai Asymp. Sig > 0,05 maka $\mathrm{H}_{0}$ ditolak, sebaliknya, jika nilai Asymp. Sig. <0,05, maka $\mathrm{H}_{\mathrm{a}}$ diterima dan $\mathrm{H}_{0}$ di tolak, artinya tidak ada pengaru mind mapping terhadap penguasaan konsep kimia pada materi hidrokarbon kelas XI MAN 1 Kota Bima.

\section{HASIL PENELITIAN}

\section{Deskriptif penelitian}

Berdasarkan penelitian yang telah dilakukan di MAN 1 Kota Bima semester ganjil Tahun Ajaran 2019/2020 dengan menerapkan mind mapping untuk melihat pengaruh penguasaan konsep siswa pada materi hidrokarbon, maka didapatkan data hasil penelitian. Data hasil penelitian didapatkan dari hasil tes. Jenis tes yang digunakan adalah jenis non obyektif karna yang diukur adalah penguasaan konsep siswa. Jumlah soal yang diberikan pada siswa sebanyak 5 butir soal.

Nilai rata-rata penguasaan konsep pada kedua kelas berbeda-beda. Nilai rata-rata dari hasil posttest siswa dari kedua kelas dapat dilihat pada tabel berikut. 
Tabel 3. Nilai Rata-Rata Penguasaan Konsep Siswa Berdasarkan Posttest

\begin{tabular}{|l|c|c|c|c|}
\hline \multicolumn{5}{|c|}{ Deskriptif statistik } \\
\hline & $\mathrm{N}$ & Minimal & Maksimal & Rata-rata \\
\hline Kelas eksperimen & 28 & 65 & 95 & 77,00 \\
\hline Kelas kontrol & 28 & 40 & 77 & 56,32 \\
\hline
\end{tabular}

Berdasarkan tabel 3. dapat disimpulkan bahwa nilai terendah siswa pada kelas eksperimen adalah 65 dan nilai tertinggi adalah 95, nilai rata-ratanya adalah 77,00. Sedangkan nilai terendah siswa kelas kontrol adalah 40 dan nilai tertinggi adalah 77, nilai rata-ratanya sebesar 56,32 .

\section{Pengujian Hipotesis}

\section{Uji prasarat}

\section{Uji normalitas}

Hasil pengujian normalitas posttest dari kelas eksperimen dan kontrol didapatkan hasil sebagai berikut:

Tabel 4. Hasil Uji Normalitas Kelas Eksperimen dan Kontrol berdasarkan Nilai posttest siswa

Tests of Normality

\begin{tabular}{|ll|r|r|r|r|r|r|}
\hline & & \multicolumn{3}{|c|}{ Kolmogorov-Smirnov } & \multicolumn{3}{|c|}{ Shapiro-Wilk } \\
\cline { 3 - 8 } & Kelas & Statistic & Df & \multicolumn{1}{c|}{ Sig. } & Statistic & \multicolumn{1}{c|}{ Df } & \multicolumn{1}{c|}{ Sig. } \\
\hline nilai & Eksperimen &, 152 & 28 &, 097 &, 894 & 28 &, 008 \\
& Kontrol &, 158 & 28 &, 072 &, 933 & 28 &, 075 \\
\hline
\end{tabular}

Nilai signifikan dari pengambilan keputusan dalam uji Normalitas Shapiro Wilk adalah 0,005. Dilihat dari tabel di atas bahwa data nilai posttest siswa kelas eksperimen tidak normal karena nilai signifikan $<0.05$, yaitu 0,008 , sedangkan nilai posttest siswa kelas kontrol adalah normal karena nilai signifikan $>0,05$ yaitu 0,075 .

\section{Uji Homogenitas}

Uji homogenitas dilakukan untuk mengetahui kelayakan atau tidaknya data berdasarkan nilai posttest pada kelas eksperimen dan kelas kontrol. Hasil uji homogenitas dapat dilihat

pada tabel berikut.

Tabel 5. Uji Homogenitas Kelas Eksperimen dan Kelas Kontrol Berdasarkan Nilai posttest siswa.

Test of Homogeneity of Variances

Penguasaan Konsep

\begin{tabular}{|r|r|r|r|}
\hline & & & \\
Levene Statistic & \multicolumn{1}{|c|}{ df1 } & \multicolumn{1}{c|}{ df2 } & Sig. \\
\hline, 567 & 1 & 54 &, 206 \\
\hline
\end{tabular}


Dari tabel di atas, dapat disimpulkan bahwa data dari kedua kelas memiliki variansi yang homogen karena nilai signifikan $>0,05$ dan data yang di dapat dari hasil uji homogenitas kelas eksperimen dan kelas kontrol berdasarkan data posttest adalah 0,206

\section{Uji Hipotesis}

Data hasil uji prasarat yaitu uji normalitas dan uji homogenitas dari data posttest pada kelas eksperimen maupun pada kelas kontrol, maka selanjutnya dilakukan uji hipotesis. Pengujian ini dilakukan menggunakan uji Mann Whitney $U$ dengan bantuan SPSS versi 22. Pengujian hipotesis mengunakan uji ini karena salah satu data tidak berdistribusi normal dan mempunyai varians yang tidak homogen. Hasil uji hipotesis dapat dilihat pada tabel berikut.

\section{Tabel 6. Hasil Uji Hipotesis Berdasarkan Data posttest Pada Kelas Eksperimen Dan Kontrol}

Test Statistics ${ }^{\mathrm{a}}$

\begin{tabular}{|l|r|}
\hline & \multicolumn{1}{|c|}{ NIlai } \\
\hline Mann-Whitney U & 44,000 \\
Wilcoxon W & 450,000 \\
Z & $-5,727$ \\
\hline Asymp. Sig. (2- &, 000 \\
tailed)
\end{tabular}

Pedoman pengambilan keputusan adalah sebagai berikut:

Jika nilai Asymp. Sig >0,05 maka $\mathrm{H}_{0}$ ditolak, sebaliknya jika nilai asymp. Sig. $<0,05$, maka $\mathrm{H}_{0}$ ditolak dan $\mathrm{Ha}$ diterima.

Berdasarkan tabel di atas dapat disimpulkan bahwa $\mathrm{H}_{0}$ ditolak dan $\mathrm{H}_{\mathrm{a}}$ diterima sehingga dapat diktakan bahwa terdapat perbedaan signifikan penguasaan konsep siswa antara kelas eksperimen dan kelas kontrol karena nilai asymp sig. Adalah 0,000.

\section{Pembahasan}

Berdasarkan hasil analisis data tes yang dilakukan oleh peneliti di MAN 1 Kota Bima, diperoleh perhitungan rata-rata penguasan konsep siswa pada materi hidrokarbon kelas XI IPA 5 (eksperimen) dengan menerapkan Media mind mapping berdasarkan hasil posttest adalah 77,00, sedangkan nilai rata-rata penguasaan konsep siswa pada materi hidrokarbon kelas XI IPA 5 (kontrol) berdasarkan hasil posttest adalah 56,32.

Setelah data diolah secara statistik yaitu dengan melakukan uji prasarat yang terdiri dari uji normalitas dan uji homogenitas, hasil pengujian menunjukan bahwa data tidak berdistribusi normal pada kelas eksperimen dan berdistribusi nomal pada kelas kontrol. Sedangkan pada uji homogenitas diperoeh data yang bervariansi homgen. Dengan demikian pada uji hipotesis dilakukan dengan menggunakan uji mann-whitney karena data yang didapat tidak berdistribusi normal. Dari uji tersebut diperoleh nilai signifikan 0,000 sehingga hipotesis $\mathrm{H}_{0}$ yang diajukan ditolak karena nilai asymp sig ditolak $<0.05$ atau $\mathrm{H}_{a}$ diterima.

Berdasarkan keterangan di atas disimpulkan bahwa terdapat pengaruh media mind mapping terhadap penguasaan konsep siswa. Media mind mapping ini sangat berpengaruh pada penguasaan konsep siswa, proses pembelajaran menggunakan mind mapping berjalan dengan lancar. Siswa bersemangat dalam belajar karena tidak merasa bosan. Hal 
ini sejalan dengan penelitian yang dilakukan oleh Dwi Selvana (2017). Hasil dari penelitian tersebut adalah penguasaan konsep siswa membaik setelah menggunakan mind mapping. Selain itu, peneliti kedua yang dilakukan oleh Rizky Agung Yulian Putra Perdana (2015). Pada penelitian ini menunjukan pengaruh penerapan mind mapping terhadap penguasaan konsep waktu dan kronologi siswa.pada penelitian ini dapat dilihat bahwa proses pembelajaran pada kelas kontrol berjalan dengan cukup baik.

\section{KESIMPULAN}

Setelah melakukan beberapa uji, penelitian ini dapat diketahui kesimpulannya bahwa mind mapping berpengaruh terhadap penguasaan konsep siswa kelas XI IPA pada materi hidrokarbon di MAN 1 Kota Bima.

\section{DAFTAR PUSTAKA}

Agung, Rizki. 2015. Pengeruh penerapan strategi mind mapping terhadap penguasaan konsep waktu dan kronologi siswa di sekolah dasar.

Buzan, dan Toni. 20008. Mind map untuk anak. Jakarta: Rineka Cipta

Dimyati, dan Midjiono. 2002. Belajar dan pembelajaran. Jakarta: Rineka Cipta

Fitriani, Baeti. 2015. Implementasi metode mind mapping pada pembelajaran fiqih di MI ALIslam Majasem Kecematan Kemangkon Kabupaten Purbalingga.

Porter, Michael, E. 2008. Strategi bersaing. Tengerang: Karisma Publishing Group

Purwanto. 2013. Evaluasi Hasil Belajar. Yogyakarta: Pustaka Belajar

Selvana, Dwi. 2017. Pengaruh media mind mapping terhadap penguasaan konsep dan habits of mind siswa kela VII pada mata pelajaran biologi di SMPN 19 Bandar Lampung.

Sholichah, Siti Aas. 2018. Teori-teori pendidikan dan Al-Quran. Jurnal pendidikan. 07 (1). 23-46

Skinner. 2013. Ilmu pengetahuan dan perilaku manusia. Yogyakarta: Pustaka Belajar Slamet. 2003. Belajar dan faktor-faktro yang mempengaruhinya. Jakarta: Rineka Cipta Sudarm, Unggul. 2016. Kimia 2 Untuk SMA/MA kelas XI. Jakarta. Erlangga.

Sugiyono. 2013. Statistika untuk ppenelitian. Bandung: Alfabeta

Svantesson, dan Igema. 2004. Learning map and memory skils. Jakarta: PT Gramedia Pistaka Utama

Tiro, A.M, dan Ahmar. 2014. Penelitian eksperimen. Makassar: Andira Publisher

Trianto. 2013. Model pembelajaran terpadu. Jakarta: Bumi Aksara 